\title{
ARTE Y MEMORIA: LOS CONTENEDORES DE MEMORIA DE ÉRIKA DIETTES
}

\author{
ART ET MÉMOIRE: \\ LES CONTENEURS DE MÉMOIRE D'ÉRIKA DIETTES
}

Emmanuelle Sinardet ${ }^{1}$

\begin{abstract}
RESUMEN: La cuestión de la memoria del conflicto interno colombiano en las obras de Érika Diettes se declina de forma muy elaborada en torno a ejes y enfoques que se completan y suplementan: memorias otras de víctimas subalternadas, primero; memorias performativas y sensibles que "hablan" directamente a los vivos, segundo; memorias reparadoras y re-humanizantes, por fin. Por la complejidad del planteamiento y la consistencia de la reflexión, las diferentes realizaciones de Diettes, Silencios (2005), Río abajo (2008), Sudarios (2011), Relicarios (2015), conforman un todo coherente a partir del cual pensar la articulación entre memoria y arte. En realidad, cada obra significa una etapa que reformula profundizándolos los planteamientos de la obra anterior, dibujando una trayectoria continua de la fabricación de dispositivos que se presentan como contenedores de memoria, no solo simbólica, sino material y físicamente. Estos contenedores de memoria pueden ser partícipes de la transición hacia una sociedad del postconflicto, pues asumen una tarea de la memoria que cumple con la doble misión de esclarecer y transformar.
\end{abstract}

Palabras clave: Memoria; arte; Colombia; conflicto interno; Érika Diettes.

RÉSUMÉ: La question de la mémoire du conflit armé colombien dans les œuvres d'Érika Diettes se décline de manière très élaborée autour d'axes qui se complètent: celui des mémoires alternatives de victimes subalternisées d'abord; celui des mémoires performatives et sensibles qui "parlent» directement aux vivants, ensuite; celui des mémoires réparatrices et réhumanisantes, enfin. En raison de la complexité des dispositifs et de la subtilité de la réflexion, les différentes réalisations de Diettes, Silencios (2005), Río abajo (2008), Sudarios (2011), Relicarios (2015), forment un ensemble cohérent à partir duquel il nous semble pertinent de penser l'articulation entre mémoire et art. Ainsi, chaque œuvre signifie une étape qui reformule en les approfondissant les enjeux posés par l'œuvre précédente, dessinant une trajectoire continue dans la fabrication de dispositifs qui se présentent, en définitive, comme des conteneurs de mémoire, non seulement symboliquement, mais aussi matériellement et physiquement. Ces conteneurs de mémoire peuvent contribuer à préparer la transition vers une société du post-conflit, car ils assument un devoir de mémoire qui remplit la double mission de lutter contre l'oubli et de transformer les perceptions.

Mots-clé: Mémoire; art; Colombie; conflit; Érika Diettes.

\footnotetext{
${ }^{1}$ Docteure en Études latino-américaines. Professeure de civilisation latino-americaine. Université Paris Nanterre, France.
} 
"La antropóloga María Victoria Uribe escribe que la violencia en Colombia es como una gran neblina, como que uno vive dentro de esta gran neblina. Para mí era literalmente así", declara la artista colombiana Érika Diettes (Cali, 1978), al evocar el asesinato de su tío en plena calle, cuando tenía 17 (entrevista con CRUZ HOYOS, 2016), enterándose la familia de la tragedia por imágenes en televisión (MÉNDEZ, 2016). Esta experiencia traumática influyó en la trayectoria original de la que estudió antropología al mismo tiempo que comenzó a dedicarse a las artes plásticas (COSOY, 2016). Al respecto, Diettes subraya la dificultad del duelo al que define como "un estado con el cual uno debe aprender a vivir" (entrevista con COSOY, 2016). Este sentimiento contribuye a la neblina, una neblina colectiva que ha ido densificándose con la repetición y reproducción de las violencias ligadas al conflicto interno colombiano. El conflicto interno, durante más de cincuenta años, se caracterizó por combates y masacres y por una serie de violencias extremas que incluyen la tortura, la desaparición forzada, los asaltos sexuales, los secuestros, los desplazamientos forzados. "Cerca de trescientos mil colombianos perdieron la vida o desaparecieron de manera forzada en el marco del conflicto armado, sin que muchas de las familias conozcan aún hoy su paradero. La geografía humana del campo y de las ciudades ha experimentado transformaciones debido a los seis millones de colombianos desarraigados de sus hogares y de sus tierras que, a pesar del dolor y del despojo violentos, se han visto obligados a reconstruir sus vidas en contextos ajenos" (Centro Nacional de Memoria Histórica, 2018, p. 11). La afectación psicosocial también ha sido y sigue siendo extrema, alimentando la impresión de una gran neblina colectiva colombiana.

La intención de Érika Diettes es precisamente ayudar a disolver la opacidad de la neblina mediante obras que enfoquen el conflicto interno desde la perspectiva de las víctimas, visibilizando su desconcierto y su dolor, su sentimiento de soledad y de impotencia. Esta neblina también puede ser interpretada como el silencio sobre las violencias cometidas, que afecta tanto a las víctimas "directas", que sufrieron en carne propia las violencias, como a las víctimas "indirectas" o "colaterales", los allegados que sobreviven la desaparición de seres queridos. De hecho, pocas veces han recibido la atención debida por parte de las autoridades, la justicia, la sociedad; no es siempre reconocido su estatuto de víctima. Sus voces quedan silenciadas, permanecen sin ecos o sin escuchar las veces que llegan a ser relevadas. Muchas víctimas callan durante años su experiencia, como lo recalcan los diferentes informes del Centro Nacional de Memoria Histórica. Tanto el silencio de las víctimas como el silencio sobre su dramática experiencia apuntan a una forma de indiferencia colectiva, de apatía, que significa una violencia más y un dolor adicional como negación del sufrimiento y, con ella, de la dignidad. Desde luego, el silencio invisibiliza a las víctimas, pero de igual manera invisibiliza a episodios del conflicto armado que remiten a la experiencia colectiva colombiana y forman parte de la realidad nacional. Como consecuencia, esta historia reciente ya es amenazada por el olvido. A la neblina del silencio, a la amenaza del olvido responden las obras de Érika Diettes que funcionan como contenedores de memoria. "Cada muestra es, para mí, una oportunidad de extender la tarea de la memoria, y digo 'tarea de la memoria' porque a esta fugitiva del tiempo, que tiende a escaparse en los silencios, esquiva y frágil ante las amenazas de la violencia, es una obligación mantenerla encendida y cuidarla de los vahos que amordazan y apagan”, escribió en su bitácora Érika Diettes en mayo de 2019.

Proponemos reflexionar cómo el arte puede hacer memoria a la luz de las estrategias estéticas de Érika Diettes, estrategias que permiten plantear la cuestión de la memoria desde la idea de contra-memoria(s), desde memorias no hegemónicas que procuran visibilizar hechos silenciados y víctimas minoradas -cuando no simplemente ignoradas- del conflicto interno del país. Nos parece que al plantear desde la perspectiva de las víctimas subalternadas la cuestión de 
la memoria, el arte de Diettes es arte "político", arte engagé, aunque dicha nominación resulte muy debatida en términos teóricos. Porque da a ver crímenes omitidos, Érika Diettes no apuesta por el arte engagé desde la denuncia, desde las reivindicaciones, desde un discurso contestatario en el que hablaría por una corriente ideológica o una organización política, sino que está al servicio de una urgencia vital: el hablar de las víctimas, permitiéndoles ser reintegradas simbólicamente en el grupo nacional. Al mismo tiempo, crear para ellas espacios de expresión autoriza la emergencia de memorias otras que (re)moldean la memoria nacional. Como intentaremos mostrar, el arte de Diettes es arte engagé precisamente por fabricar simbólica y literalmente- contenedores de memorias en plural.

Las obras de Érika Diettes se sitúan en la encrucijada de varios enfoques y disciplinas, artes plásticas, fotografía, instalación, historia, antropología y psicología. Asumen un papel saludable, terapéutico incluso, que tiene una función social: hacer memoria mostrando y recordando "todo eso que no debió pasar", en palabras de la socióloga Nadis Londoño (citada en CRUZ HOYOS, 2016). Gracias a la sublimación estética que suscita la labor artística, los recuerdos de las víctimas abren nuevas perspectivas, perspectivas constructivas para la sociedad colombiana que miran a futuro. Efectivamente, los dispositivos de Diettes son revelaciones, primero porque desvelan al público lo que este ignora o va olvidando, pero también porque recurren a la fotografía, o sea, literalmente, a una revelación: la fotografía revela y fija lo revelado física y materialmente, funcionando como un contenedor de la memoria.

De ello da fe la primera obra de Diettes, en 2005, Silencios. El dispositivo fotográfico ya puede ser considerado como una obra de memoria, mejor dicho, de contra-memoria, pues evidencia una memoria alternativa, de hecho poco presente en el imaginario colombiano: la Shoah. Para el espectador, los silencios que dan a la obra su título remiten tanto a los hechos silenciados por las víctimas retratadas, sobrevivientes judíos de la persecución nazi, refugiados en Colombia después de la Segunda Guerra Mundial, como a una suerte de olvido y de indiferencia de parte de la sociedad. Silencios es una serie destinada a romper el silencio, pues la conforman 30 elementos fotográficos constituidos en base a un tríptico de imágenes de gran formato en blanco y negro que "revelan": primero, el retrato en primer plano de la víctima de la Shoah; segundo, un breve texto-testimonio redactado manualmente por ella; por fin, un objeto del pasado que la vincula directamente con la experiencia de la persecución, en su mayoría una vieja fotografía de familiares desaparecidos, siendo ésta la única huella que queda de ellos. Mediante este dispositivo, paradójicamente, los silencios hablan y dicen más que las palabras. De hecho, Diettes trabajó en el silencio con el primero de los sobrevivientes que accedió a ser fotografiado, Maximilian Kirshberg: éste le puso como condición que no se le hiciera ninguna pregunta (DIETTES en su bitácora, 2020). Pero los retratos inmensos se imponen al espectador: suspendidos a la altura del público en un face à face ineludible, le interpelan y no pueden sino ser escuchados. El uso del blanco y negro refuerza la idea de transmisión de eventos "verdaderos" que deben ser recordados, pues el blanco y negro es "la paleta de color en la memoria visual de muchos acontecimientos históricos, dotando de cierta sensación de perduración temporal, eternidad y dramatismo a las imágenes" (OLAYA; IASNAIA, 2012, p. 135). El dispositivo fotográfico de Silencios utiliza los códigos de la fotografía documental para producir imágenes-testimonios destinadas a rememorar. Notemos que no están representadas las violencias vividas, lo cual caracteriza, por cierto, todas las obras de Diettes: es mediante el testimonio de los sobrevivientes, con silencios que hablan, como se indica el crimen. El dispositivo se hace memoria por producir ecos de palabras nunca pronunciadas, con gran fuerza emocional. 
En 2008, Río Abajo también procura "revelar" lo silenciado e invisibilazado, en este caso a los que literal y concretamente han sido invisibilizados, a las víctimas asesinadas del conflicto armado interno, cuyos cuerpos han sido descuartizados, tirados al río y han desaparecido sin dejar rastro. El título remite a la doble aniquilación de las víctimas, por el asesinato y por la negación del crimen mediante la eliminación de las huellas, tragadas por las aguas. La obra tampoco describe las terribles violencias; sin embargo, con gran delicadeza, de forma muy hábil y sutil, las va señalando en creux. En efecto, Río Abajo es una serie de 26 fotografías digitales en color, impresas en piezas de cristal de 150 x $88 \mathrm{~cm}$, que muestran una prenda de vestir del desaparecido, prestada a la artista por familiares oriundos de la región de Antioquia, muy afectada por las violencias del conflicto (DIETTES; DIÉGUEZ; TUCKER, 2016). Fotografiada en un medio acuático límpido, la prenda parece estar flotando y funciona como la metonimia que designa a los restos humanos, al cuerpo que va "río abajo". El dispositivo restaura la presencia del cuerpo ausente y, con ello, "revela" el crimen cometido.

Río Abajo articula una tensión ausencia-presencia en torno a la noción de huella según la acepción de Walter Benjamin (SINARDET, 2016). Cada fotografía, a partir del objeto del desaparecido, crea una huella cuando ya no la hay. Ahora bien, la huella no es sino "la aparición de una cercanía, por lejos que pueda estar lo que la dejó atrás", por lo que "en la huella nos hacemos con las cosas" (BENJAMIN, 2005, p. 450). Con Río Abajo, nos "hacemos con" los desaparecidos y su dolor, con su experiencia y su historia. Desde luego, tal dispositivo fabrica memoria, pues la "cercanía" de las huellas se entiende como la actualización del pasado en el presente. Para Benjamin, en efecto, la huella no es únicamente un indicio de hechos acontecidos: es también, en sí, un material y una forma de espacio que actualiza el pasado.

Simultáneamente, Río Abajo diseña un cementerio en el espacio de la exposición; las grandes piezas de cristal en las que están impresas las fotografías-huellas no están colgadas, sino dispuestas en el suelo a manera de estelas, de piedras funerarias entre las que puede avanzar y pasear el espectador. El dispositivo genera un sentimiento de serenidad que invita al recogimiento, con tristeza, cierto es, pero sin dramatismo morboso, por la belleza de las fotografías-estelas, luminosas todas, por la transparencia de las aguas representadas, por la sensación del movimiento suave que va llevando a la prenda-huella-cuerpo. La emoción del público nace tanto de la presencia de los difuntos, una presencia restaurada después de haberles sido negada, como del reconocimiento de su sufrimiento, pues la metonimia apunta a una violencia adicional, a la negación de la dignidad que significa la negación misma del crimen. Restituida su humanidad, las víctimas pueden por fin descansar, y el espectador es partícipe de la transformación simbólica del espacio en un camposanto, al desplazarse, conmovido, entre las fotografías-estelas. Para Érika Diettes, "los ríos de Colombia son el cementerio más grande del mundo" (entrevista a Capital Cultura, 2010) y Río abajo es la patente realización artística de esa aseveración. A primera vista, descalifica la tradicional metáfora del río como fuente de vida o como elemento de comunicación que une a los hombres, pues remite a la violencia y a la muerte, es más, a métodos aberrantes de eliminación de las víctimas. Precisamente, el trabajo artístico de Diettes consiste en plasmar un río que permita restaurar la dignidad, negando la aniquilación y el olvido, como promesa de una posible reconciliación con un pasado traumático. En realidad, Río abajo trasciende los espacios mortíferos del silencio en espacios de memoria viva. Como dicho, va fabricando huellas-memorias que actualizan el pasado en el presente. Pero el dispositivo también fabrica una imagen que es "survivance", "supervivencia" (DIDI-HUBERMAN, 2009): la imagen solicita no solo a la mirada del espectador, sino a toda su persona, a su persona como una totalidad sensible, cultural, psicológica, que experimenta la experiencia de la víctima y comparte su dolor. 
Las dinámicas memoriales presentes en Silencios y en Río Abajo procuran "revelar", o sea, al mismo tiempo desvelar y fijar fotográficamente lo desvelado de forma definitiva; "revelan" las palabras nunca pronunciadas, "revelan" la presencia del desaparecido con una huella que habla por él. Tales dinámicas se encuentran en otra obra con fuerte carga emocional, Sudarios (2011), unos veinte retratos en blanco y negro, de primer plano en fondo oscuro, impresos en elegantes velos de seda de $2,28 \mathrm{~m}$ por $1,34 \mathrm{~m}$, colgados en espacios sagrados, iglesias en su mayoría, en los que parecen estar flotando. La serie Sudarios es el resultado de un trabajo colaborativo con otras víctimas de las violencias del conflicto, mujeres humildes de la región de Antioquia que han sido obligadas a presenciar las torturas infligidas a seres queridos (DIETTES, 2012). La serie inició con el testimonio de una mujer forzada a ver cómo a su madre le arrancaban los ojos y le cortaban la lengua (CRUZ HOYOS, 2016). En presencia de una psicóloga, después de varios encuentros y entrevistas, Diettes capta la imagen de las mujeres cuando narran el momento más dramático de la traumática experiencia. La preparación minuciosa de las sesiones fotográficas, la relación de confianza instaurada con las víctimas, la dinámica colaborativa del proceso, forman parte de la obra, siendo la fotografía y su impresión en la seda la etapa última del trabajo de fabricación de la obra. En otras palabras, la fotografía es más que una imagen: es testimonio y está destinada a "hablar". Es narrando el clímax del dolor cómo "revela" la violencia y los crímenes: capta lo latente para hacerlo visible, capta lo inefable para hacerlo discurso. Es que, siendo aquí una colaboración, el arte no recae en la artista sino en esas mujeres cuyas voces no han sido escuchadas. Por lo que Sudarios, al mismo tiempo que les ofrece un espacio de expresión, las empodera y las agencia al autorizarlas a desarrollar un discurso propio. La artista no se sustituye a las mujeres retratadas, no habla por ellas, no las trata como a modelos. Al contrario, crea las condiciones para que éstas puedan elaborar su message y dialogar directamente con el espectador. Son emprendedoras de memoria, según la bella expresión de Avendaño-Ramírez y Villa-Gómez, ya que asumen, gracias a Diettes, "un papel educativo frente a las nuevas generaciones y uno confrontador de versiones oficiales que pretenden ocultar la historia" (2017, p. 508).

El diálogo directo con el espectador y la empresa de memoria los permite el dispositivo de Sudarios al elaborar una memoria performativa que "se ubica en la dimensión corporal y emocional" (AVENDAÑO-RAMÍREZ; VILLA-GÓMEZ, 2017, p. 510). Pensamos de nuevo en el fenómeno de la survivance (DIDI-HUBERMAN, 2002) ante esas imágenes impresas en seda y que flotan en los aires de las iglesias; convocan la sensibilidad del espectador, como lo observa la antropóloga Ángela María Duarte describiendo la reacción del público de Sudarios:

Sin embargo, esta experiencia del dolor de aquellos rostros que vieron y vivieron un dolor inimaginable y ajeno a nosotros, "nos toca". Ante este sufrimiento hay sentimientos de por medio, "hay" un cuerpo y una sensibilidad del espectador que no pueden negarse ${ }^{2}$ [...]. (DUARTE, 2015, p. 3)

A la survivance, a la memoria performativa del dolor, a la reactualización en el presente de las trágicas experiencias del pasado, contribuye el espacio de la exposición, íntimamente vinculado con lo sagrado: la iglesia. Los retratos están invadidos por un dolor infinito mediante una composición que no deja espacio para ningún otro sentimiento: rostros que ocupan todo el

\footnotetext{
${ }^{2}$ Reproducimos la tipografía original.
} 
espacio de la imagen, extrema sencillez y depuración incluso, hombros desnudos, blanco y negro en un fondo oscuro sin decoro, ningún detalle que le distraiga al espectador de la contemplación de caras compungidas y contraídas, con ojos cerrados y bocas entreabiertas. El material en que vienen impresos estos retratos del dolor designa metafóricamente la muerte: los velos remiten a los sudarios de las víctimas asesinadas, que le dan a la obra su nombre. Sobre todo, estos velos-sudarios expuestos en el centro de la iglesia otorgan al dolor una dimensión crística que evoca la Pasión. Ahora bien, si la Pasión remite al sufrimiento, también anuncia que este no desembocará ni en el aniquilamiento ni en el olvido, pues la Pasión prepara una Resurrección que es nueva vida y nueva presencia. Las fotografías-sudarios son trascendidas en un mensaje colectivo de esperanza por la sacralidad del Misterio que se repite en el recinto de la iglesia durante cada celebración y cada misa. No se trata de negar el dolor -al contrario, está expuesto-, sino de sublimarlo para hacer de él memorias transformadoras y reformadoras. Al respecto, impacta la elegancia y la belleza de los retratos, pero no se trata de una estetización del dolor: estas mujeres sufrientes y bellas son representaciones universales, son mater dolorosa (SINARDET, 2016). Mediante lo sagrado del espacio y el Misterio que supone, los retratos escapan del academismo tradicionalmente asociado con el tópico de la Pietà para ser convertidos en figuras auráticas que "hablan" de forma performativa. Como presencias inmanentes, "narran" su experiencia, la transmiten y luchan contra el olvido, haciendo memoria. El dispositivo de Érika Diettes no describe ni denuncia, sino que crea presencias auráticas que establecen vínculos entre el pasado y el presente, entre la víctima y el espectador, entre los muertos y los vivos, invitando a asumir y compartir una memoria que no es repetición del dolor, sino invitación a construir un futuro nuevo.

Las obras de Diettes funcionan todas como contenedores de memoria que "revelan" y le "hablan" directamente al público merced a huellas metonímicas y figuras auráticas. Tal dinámica artística nos parece culminar con la obra Relicarios, fruto de un largo trabajo colaborativo realizado entre 2011 y 2015, mostrada por primera vez en el Museo de Antioquia entre noviembre de 2016 y abril de 2017, en una de las regiones más afectadas por las violencias del conflicto interno. Desde 2011, Érika Diettes ha ido viajando por el país para visitar a familias enlutadas, escuchar su pena, recoger los testimonios de su experiencia del conflicto, reunir sus recuerdos de los desaparecidos, ofreciéndoles que le entregasen un objeto emblemático del difunto (SINARDET, 2019). Este proceso colaborativo ya se había iniciado con Rio Abajo, pero con Relicarios ya no se trata de prestar la pertenencia del ausente, sino de cederla a la artista. Relicarios, como lo indica el título de la obra, consiste en trascender estéticamente tal pertenencia en reliquia. La artista ya no utiliza la fotografía: fabrica cápsulas que conservan material y físicamente -y no solo simbólica y metafóricamente- aquel objeto, impidiendo su restitución a los allegados. De hecho, Relicarios conserva doblemente: por un lado, la artista guarda con ella el objeto de forma definitiva; por otro lado y al mismo tiempo, lo protege de los daños del tiempo y lo preserva de toda degradación. Desde esta perspectiva, Relicarios prolonga el proceso de Río Abajo que transformaba el objeto en metonimia del cuerpo y este en huella benjaminiana para restaurar la presencia del ausente. Pero va más lejos, en la medida en que crea una huella indeleble e inalterable, intacta para siempre. Dicho de otro modo, Relicarios no solo hace memoria, es memoria. Desde luego, "revelar" sigue siendo el propósito de Relicarios, pero el dispositivo está pensado para transmitir tal revelación a las siguientes generaciones, más allá del actual público. No es casualidad si el Centro Nacional de Memoria Histórica y la Comfama, una corporación privada sin ánimo de lucro, auspiciaron el proyecto: Relicarios fabrica "contenedores de memoria" en el sentido primero de la palabra y desafía el transcurrir 
del tiempo (TORO VEGA, 2017).

Al respecto, una de las dificultades ha sido definir la técnica de conservación idónea, lo que contribuye a explicar el largo proceso de elaboración de la obra, de casi cinco años. La solución adoptada fue el tripolimero de caucho, un material translúcido y cálido, de fuerte potencial estético, que evoca el ámbar por su textura y su color. El objeto perteneciente al difunto está bañado en el tripolimero de caucho dentro de cápsulas de cristal cuadradas de 30 $\mathrm{cm}$ con espesor de $12 \mathrm{~cm}$. Evidentemente, el proceso recuerda la fosilización en el ámbar, capaz de retar el tiempo y, con ello, de vedar el olvido. El objeto conservado se asemeja a aquellas inclusiones en el ámbar que encarnan periodos concluidos y acontecimientos remotos de los que casi nada ha permanecido, permitiendo su pervivencia en el presente. Por lo que no solo porta memorias la cápsula, sino que es memoria.

Para tal lógica memorial, la dimensión estética es primordial: el tripolimero recuerda el ámbar, material noble que hace de las cápsulas unas urnas preciosas destinadas a recibir los objetos en los que han sido invertidos afectivamente los desaparecidos. Al sublimar los objetos en inclusiones en el tripolimero/ámbar, Diettes les restituye el valor inestimable que les conceden los familiares afligidos por la pérdida (DIETTES en su bitácora, 2020). Se considera el ámbar como una gema; objetos muy triviales, irrisorios incluso, un peluche, la camiseta del equipo de futbol, una cédula o una pequeña fotografía, únicos vestigios, están convertidos en gemas preciosas cuya belleza dice la crueldad de la desaparición y la inmensidad de la pena. Diettes insiste: "Son prendas que estuvieron en contacto con los cuerpos de los ausentes, que están impregnados de su aura, de sus olores, que portan una memoria sensible y que en ocasiones pasaron por más de una generación de familias" (DIETTES en su bitácora, 2020) ${ }^{3}$. Son a esas memorias "sensibles" a las que conservan los contenedores de memoria de Relicarios.

Como en Río Abajo, la tensión ausencia-presencia la crea el objeto: como único resto, apunta a la muerte y a la ausencia, "revelando" también el crimen cometido; como metonimia del cuerpo, restaura la presencia del difunto que puede "hablar" y contar. La artista convoca esta presencia gracias al delicado trabajo sobre la luz. Las cápsulas están colocadas en una base que ilumina los tripolimeros-ámbares, sugiriendo una presencia inmanente. Notemos la ausencia de toda morbididad y dramatización: la luz apacigua y dice la vida. Además, la iluminación participa de la sacralización del objeto. Este ha sido guardado con amor durante años, como una reliquia, comenta Diettes (en su Bitácora, 2020) quien, con el arte, procura fabricar relicarios que preserven dichos objetos. La estructura transparente de las cápsulas remite a las cajas de cristal donde se exponen reliquias de santos en las iglesias. Por añadidura, si bien las cápsulas-relicarios evocan el martirio de los difuntos y sus asesinatos, también recuerdan que no han sido destruidos ni exterminados: como contenedores de restos sagrados, las cápsulas-relicarios invocan ese Misterio que desafía la muerte y el olvido. El Misterio lo insinúa la luz ascendiente emitida desde la base que alumbra el ámbar, como si este fuese la fuente de toda iluminación. Con este dispositivo muy elaborado, los objetos se convierten en "verdaderas" reliquias, es decir, en presencias auráticas y esenciales.

A diferencia de la huella que es prolongación del ausente, la reliquia es presencia: el espíritu del difunto, el alma misma, residen en ella. Diettes cita una anécdota que da fe de ello. Una mujer le explicó, al entregarle el recuerdo de su hermano, que este siempre había deseado viajar y que por fin se realizaría su ilusión: "Yo siempre soñé que mi hermano estuviera en una de [las] obras [de Érika Diettes] (había visto Río Abajo ${ }^{4}$ ), porque él siempre quiso recorrer el

\footnotetext{
${ }^{3}$ El subrayado es nuestro.

${ }^{4}$ Después de las primeras muestras en la región de Antioquia, Río abajo no ha dejado de viajar tanto en Colombia
} 
mundo y ahora lo va a poder hacer" (citado en COSOY, 2016). Lo vemos, no es la huella del ausente la que debe viajar ${ }^{5}$, sino el mismo hermano. Ahora bien, si admitimos que está presente, entonces puede hablar y testimoniar.

En el arte de Érika Diettes, la cuestión de la memoria viene estrechamente asociada con una forma de reconocimiento, de rehabilitación y de reparación, que ella procura hacer emerger, preservar y transmitir contra-memorias que no han sido tomadas en consideración. Al mismo tiempo, estas memorias, gracias a las obras de Diettes, son memorias vivas, performativas y sensibles. Como tales, llevan consigo una dimensión terapéutica para las víctimas del conflicto interno y también para la sociedad colombiana (ARCOS-PALMA, 2010). En efecto, el arte de Diettes consiste en hacer el camino exactamente inverso al de la deshumanización inherente a las violencias del conflicto. Su propósito es dignificar. Cuando los asesinos han borrado todo rastro del cuerpo, Érika Diettes elabora una huella que restaura su presencia; cuando los verdugos han cosificado y reificado a las víctimas, las trata como a personas.

La reparación es un proceso medular en la obra Sudarios, en la que las mujeres retratadas también expresan los dolores del no reconocimiento de su pena, del silencio del Estado, de la impunidad de los torturadores y verdugos, del desinterés de la sociedad. Sudarios justamente contribuye al reconocimiento de aquellos dolores plurales y multifacéticos, ya que, lejos de ser el face à face entre el modelo y la artista, el dispositivo fotográfico de la obra se presenta como un caminar colectivo de mujeres que se reconocen en el sufrimiento, que se solidarizan y se acompañan mutuamente (COSOY, 2016). Encima, por funcionar como un contenedor de memoria, la obra permite que las mujeres retratadas depositen en ella la remembranza mórbida y obsesiva de sus experiencias traumáticas. Pues la rememoración rumiada es otra violencia para ellas, como lo recuerda Érika Diettes en una entrevista: "These women want to relay the moment in which they were condemned to remember, given that the possibility of forgetting even the smallest detail does not exist" (SMITHSON, 2015). Sudarios se hace cargo de los recuerdos traumáticos y alivia a las víctimas. Por lo que, si bien es cierto que es "arte como memoria del dolor" (DIEGUEZ, 2015, p. 1), también es arte terapéutico.

Por su parte, Río abajo simbólicamente efectúa los rituales funerarios que les han sido negados a las víctimas asesinadas y descuartizadas, tiradas al río sin que las familias pudieran dar con ellas; la realización de los ritos funerales las vuelve a humanizar. Desde esta perspectiva, también alivia la pena de los familiares facilitando el trabajo del duelo. La fotografía capta la huella del difunto, la estetiza con una composición apaciguadora y serena, restituye a los allegados el cuerpo en toda su integridad, con su juventud, su luz y su aura. La belleza de la composición es partícipe de la dignificación y rehumanización, como lo subraya la antropóloga Silvia Monroy Álvarez al observar la reacción de las familias de los ausentes ante la obra:

Vi [a las personas] reparando en cada detalle de los objetos fotografiados, buscándose en ellos, identificándose en ellos. Muchos de los presentes en aquel instante resaltaban la belleza de las fotografías de Érika y el esmero por

como en el extranjero, al Centro Cultural Recoleta en Buenos Aires en 2008, a la De Santos Gallery en Houston en 2008, al Palacio de la Inquisición de Cartagena en 2009, al Newark Arts Councils en Newark-USA en 2009, al Museo de Arte de la Universidad Central en Bogotá en 2010, a la iglesia El Señor de las Misericordias en Medellín en 2014, a la iglesia Nuestra Señora de las Nieves en Bogotá en 2014.

${ }^{5}$ Relicarios, efectivamente, debe estar mostrada en varias ciudades y países después de las exposiciones en marzo de 2018 en Buenos Aires y en 2019 en Bogotá. 
crear un espacio bello. Y es por este tipo de reacción que la artista logró confirmar que lo bello es una condición primordial para dignificar a quien ha padecido sufrimiento y dolor. La rama de un pino, una camisa, un pantalón, una caña de pescar, un documento, una foto, una libreta de calificaciones dejan de ser objetos, son agentes del mundo sensible; son materiales vivos, cargados de significados y elevados a la calidad de personas. Y esto porque las cosas están dotadas de cualidades que las validan para interactuar en el mismo nivel de las relaciones sociales de las personas humanas. (MONROY ÁLVAREZ, 2009)

El espacio de la exposición funciona como un cementerio, como dicho, y las primeras exposiciones tuvieron lugar en pueblos de la región de Antioquia particularmente impactados por el conflicto interno. En 2008, en la Casa de la Cultura de Granada, con ocasión de un acto memorial, el público, con una vela en la mano, deambuló por entre las fotografías-estelas creando un ritual para las muertos y para los sobrevivientes: "En ese mismo instante se opera algo: se realiza un duelo por aquel ser a quien se sigue esperando", comenta Ricardo ArcosPalma (2015, p. 7), el director del Museo de Arte de Bogotá donde también fue mostrada Río abajo. Es que, en ausencia de todo rastro del ser querido, los allegados conservan la ilusión de su retorno, viviendo otro dolor más, el de la esperanza repetitivamente decepcionada. Río abajo, al ofrecerles una estela funeraria, les autoriza el saludable trabajo del duelo.

Relicarios, asimismo, procura facilitar el trabajo del duelo. Ciertas familias hicieron un largo y difícil viaje para acudir a Érika Diettes y regalarle el objeto emblemático de sus difuntos, porque estaban en busca de un "lugar digno" para sus reliquias y las entregaron "como si se depositaran en un templo" (DIETTES en su Bitácora, 2020). Es que, como lo recuerda Nadis Londoño, la socióloga que participó en el proyecto,

Lo que hacemos con Relicarios es crear un espacio de empatía y escucha con las personas que traen los objetos y que nos cuentan su historia. No es recibir el objeto por recibirlo, sino que hay un espacio de validación de la historia, de reconocer ese dolor. También es un espacio para que las víctimas de la violencia puedan tener un lugar público para ese dolor. (citado en CRUZ HOYOS, 2016)

Para muchos, aquel regalo significó una etapa primordial de la aceptación de la muerte. El gesto de depositar el objeto también permitió depositar parte de su pena, ya que "desprenderse de un objeto de un ser querido desaparecido o asesinado es también compartir el sufrimiento, aliviar la carga, procesar el duelo (citado en CRUZ HOYOS, 2016), como recalca Nadis Londoño.

Por fin, como Río abajo, Relicarios es una instalación que crea las condiciones para la expresión del dolor y del duelo de las familias afligidas. La artista dispuso en alineaciones simétricas las 165 cápsulas de la obra, a manera de filas de lápidas funerarias en un cementerio. En la inauguración de Relicarios, en noviembre de 2016, unos trescientos familiares viajaron al Museo de Antioquia en Medellín donde fueron recibidos y acompañados por el personal del Museo y por psicólogos, para inclinarse no en cápsulas, sino en las tumbas de sus seres queridos, exteriorizando su dolor y liberándose de la pena. No parece exagerado hablar de un momento catártico. Para Ileana Diéguez, curadora de la exposición, "Relicarios es mucho más que un proyecto artístico. Es una obra en duelo. Una paciente y sostenida acción que desde los 
espacios y las estrategias del arte ha devenido un ritual que dignifique el dolor de las muchas familias que lloran la pérdida violenta de sus seres queridos, sin que nunca llegue la justicia.” (DIEGUEZ, 2016)

La misión reparadora del arte de Diettes no es anecdótica ni secundaria en la "tarea de la memoria": es complementaria y representa una de las condiciones imprescindibles para promover una sociedad de la convivencia, pacificada y apaciguada. Favorecer el trabajo del duelo, de todos los duelos del conflicto interno, representa incluso, según Diettes, un reto de salud pública y un desafío colectivo para Colombia (entrevista con CRUZ HOYOS, 2016). Al dejar que los muertos "hablen", estas obras principalmente se dirigen a los vivos, invitándoles a llevar a cabo un proceso de aceptación y progresiva reconciliación con el pasado reciente del país. En Relicarios, la artista dispuso las cápsulas-relicarios-lápidas en el espacio de la exposición de tal forma que guiasen al público en la oscuridad voluntaria de la sala: "Es como si a partir del testimonio de estas víctimas podamos iluminar la luz de la historia" (citado en MONCADA ESQUIVEL, 2015). Ahora bien, porque logran prender la "luz de la historia", los contenedores de memoria de Diettes también son promesas de conciliación y paz.

\section{Conclusión}

La cuestión de la memoria en las obras de Érika Diettes se declina de forma particularmente densa y elaborada en torno a ejes y enfoques que se completan y suplementan: memorias otras de víctimas subalternadas, primero; memorias performativas y sensibles que "hablan" directamente a los vivos, segundo; memorias reparadoras y re-humanizantes, por fin. Por la complejidad del planteamiento y la consistencia de la reflexión, las diferentes realizaciones de Diettes, Silencios (2005), Río abajo (2008), Sudarios (2011), Relicarios (2015), conforman un todo coherente y homogéneo a partir del cual nos parece pertinente pensar la articulación entre memoria y arte. En realidad, cada obra significa una etapa que reformula profundizándolos los planteamientos de la obra anterior, y va dibujando una trayectoria continua de la fabricación de dispositivos que se presentan como contenedores de memoria no solo simbólica, sino material y físicamente. A nuestro parecer, el arte puede contribuir preparándola a la transición hacia una sociedad del postconflicto cuando, como aquí es el caso, rebasa en un ejercicio de la memoria que asume la doble misión de esclarecer y transformar. No es memoria para dar buena conciencia y mejor olvidar luego, aún menos para perdonar, sino para crear las condiciones propicias para la conciliación ta conciliación antes que la reconciliación, pues la reconciliación solo es posible con el perdón, y el perdón no puede ser exigido, como bien recuerda Paul Ricoeur, incluso legítimamente puede ser negado (RICOEUR, 2000). Al respecto, nos parece que tal conciliación no solo debe ser la de las víctimas con los victimarios, sino también la de las víctimas con el mismo Estado que ha tolerado abusos, injusticias y una impunidad que dificultan un apaciguamiento a futuro. El arte suscita una tarea de la memoria que devela y "revela", como lo hace Diettes, las complicidades, la indiferencia, las omisiones de la institucionalidad. Puede favorecer la conciliación al mostrar, a manera de espejo, a la sociedad como conjunto, más allá de las instituciones, su propia apatía frente a las tragedias del conflicto. No se trata de echar culpas, sino de admitir responsabilidades y de aceptar que el dolor individual también es un dolor colectivo. Pues es asumiendo que el dolor de la víctima también es el dolor de un ciudadano cómo la sociedad podrá llegar a reconocerse en su experiencia. El arte permite justamente que los duelos individuales e íntimos pasen a ser el duelo colectivo de conciudadanos. 
Es posible que, como lo sugiere Bruno Tertrais, "[...] haya un momento para el olvido y otro para la memoria" (2019, s. p.). Sin embargo, nos parece que "la memoria nos abre camino" ${ }^{6}$, porque si una sociedad renuncia a la tarea de la memoria y prefiere el olvido -por cierto, cómodo y tranquilizador-, corre el riesgo de la reaparición y de la repetición de lo olvidado. El abrirnos camino mediante contenedores de memoria es el engagement del arte de Diettes. La lucha contra el silencio y el olvido le ha valido a Érika Diettes, en 2017, ser galardonada con el prestigioso premio Tim Hetherington Fellowship que apoya los proyectos artísticos al servicio de los derechos humanos (World Press Photo Foundation, 2017). El premio nos parece particularmente pertinente y merecido por distinguir un arte engagé en la tarea de la memoria que prepara la sociedad del postconflicto, que contribuye a crear las condiciones para la (re)conciliación y, con ello, que combate el surgimiento de fantasmas del pasado y la repetición de atrocidades.

\section{Bibliografía}

ARCOS-PALMA, R. Río abajo de Érika Diettes. 2010. Disponible en: <http://static1.squarespace.com/static/54918f84e4b0b437af2bbcf0/t/54937b34e4b011bd5620 9fc8/1418951476212/rioabajoRAP.pdf>.Accedido el: 14 feb 2020.

AVENDAÑO-RAMÍREZ, M., VILLA-GÓMEZ, J.D. Arte y memoria: expresiones de resistencia y transformaciones subjetivas frente a la violencia política. Revista Colombiana de Ciencias Sociales, v. 8, número 2, p. 502-535, julio-diciembre 2017.

BENJAMIN, W. Libro de los pasajes. Madrid: Akal, 2005.

Capital Cultura. Capitulo 1 Bosque Izquierdo 2. Mar 2010. Disponible en: <https://www.youtube.com/watch?v=7VjlgBiYFZE >. Accedido el: 14 feb 2020.

Centro Nacional de Memoria Histórica. La memoria nos abre camino. Balance metodológico del CNMH para el esclarecimiento histórico. Bogotá: CNMH, 2018. También disponible en: $<$ http://centrodememoriahistorica.gov.co/wp-

content/uploads/2020/01/LA_MEMORIA_NOS_ABRE_CAMINO.pdf>. Accedido el: 15 feb 2020.

COSOY, N. "Estas son mis reliquias": entregar para el arte los objetos de un familiar muerto. BBC Mundo, 92016.2 abr Disponible en: <http://www.bbc.com/mundo/video_fotos/2016/04/160408_fotos_erika_diettes_relicarios_m emento_mori_nc>. Accedido el: 20 feb 2020.

CRUZ HOYOS, S. Érika Diettes y el arte de encontrar belleza en el dolor. El País, 26 jun 2016. Disponible en: <http://www.elpais.com.co/entretenimiento/cultura/erika-diettes-y-el-arte-deencontrar-belleza-en-el-dolor.html>. Accedido el: 20 feb 2020.

DIDI-HUBERMAN, G. Survivance des lucioles. Paris: Éditions de Minuit, collection Paradoxe, 2009.

DIDI-HUBERMAN, G. L'image survivante. Histoire de l'art et temps des fantômes selon Aby Warburg. Paris: Éditions de Minuit, collection Paradoxe, 2002.

\footnotetext{
${ }^{6}$ Retomamos el título del informe del Centro Nacional de Memoria Histórica (2018).
} 
DIÉGUEZ, I. Presentación de Relicarios. 2016. Disponible en: <https://www.museodeantioquia.co/exposicion/relicarios/>. Accedido el: 20 feb 2020.

DIETTES, É. Bitácora. Disponible en: <http://www.erikadiettes.com>. Accedido el: 13 feb 2020.

DIETTES, É. Charla sobre la muestra Sudarios. May 2012. Disponible en: <https://www.youtube.com/watch?v=xFB5WERb0UA>. Accedido el: 21 feb 2020.

DIETTES, É., DIÉGUEZ, I., TUCKER, A. Memento Mori, Testament to Life. Stauton-USA: George F. Thompson Publishing, 2016.

DUARTE, Á.M. Los "silencios del dolor": una lectura del aspecto táctil de Sudarios de Erika Diettes. 2015. Disponible en: <http://grupoleyyviolencia.uniandes.edu.co/Web/documentos/ponenciaChile2.pdf >. Accedido el: 15 feb 2020.

GRUPO de Memoria Histórica. ¡Basta Ya! Colombia: memorias de guerra y dignidad. Centro Nacional de Memoria Histórica: Bogotá, 2013.

MÉNDEZ, M.G. Transformar el duelo de un país. Revista Bienestar Sanitas, número 144, 18 ago 2016. Disponible en: <https://bienestarcolsanitas.com/articulo/erika-diettes.html>. Accedido el: 20 feb 2020.

MONCADA ESQUIVEL, R. La artista caleña Érika Diettes habló de su proyecto "Relicarios". El País, 10 feb 2015. Disponible en: http://www.elpais.com.co/entretenimiento/cultura/laartista-calena-erika-diettes-hablo-de-su-proyecto-relicarios.html. Accedido el: 15 feb 2020.

MONROY ÁlVAREZ, S. Río Abajo, una exposición de Érika Diettes. Antípoda, Bogotá, número 8, p. 197-200, enero-junio 2009. Disponible en: <http://antipoda.uniandes.edu.co/view.php/131/view.php>. Accedido el: 16 feb 2020.

OLAYA GUALTEROS, V., IASNAIA SIMBAQUEBA, M. Estetización de la memoria: formación y espacios de lo político. Revista Colombiana de Educación, Bogotá, número 62, p. 117 138, primer semestre 2012.

RICOEUR, P. La Mémoire, l'Histoire, l'Oubli. Paris: Seuil, 2000.

SINARDET, E. Rendre visibles les disparus en Colombie: Relicarios d'Érika Diettes (2011-2015). In: ELMALEH, E., MICHAUD, M.C., OUELASTI, S. (org). Faces cachées dans les Amériques. Le Mans: Eric Jamet éditeur, 2019, p. 263-280.

SINARDET, E. Néantisation et lutte contre l'oubli: la représentation de la violence des conflits armés colombiens dans deux œuvres photographiques d'Érika Diettes, Río abajo (2008) et Sudarios (2011). Les Cahiers ALHIM (Amérique latine Histoire et Mémoire), La représentation des violences de l'Histoire dans les arts visuels latino-américains (1968-2014), número 30, ene 2016. Disponible en: <http://alhim.revues.org/5350>. Accedido el: 15 feb 2020.

SMITHSON, A. Latin America week: Erika Diettes. Lens/cratch, 23 oct 2012. Disponible en: <http://lenscratch.com/2012/10/latin-american-week-erika-diettes/>. Accedido el: 16 feb 2020.

TERTRAIS, B. La venganza de la historia: cómo el pasado está cambiando el mundo. Edición digital: RBA Libros, 2019.

TORO VEGA, M. A. Érika Diettes presenta su obra "Relicarios" en el Museo de Antioquia. El 
Tiempo, 15 ene 2017. Disponible en: <http://www.eltiempo.com/archivo/documento/CMS16793164>. Accedido el: 16 feb 2020.

WORLD PRESS Photo Foundation. Announcing the 2017 Tim Hetherington Fellowship. 2017. Disponible en: <https://www.worldpressphoto.org/news/2017-04-26/announcing-2017-timhetherington-fellowship>. Accedido el: 18 feb 2020.

Recebido em: 22/02/2020

Aceito em: 02/04/2020 